Наносистели, нанолатеріали, нанотехнології Nanosistemi, Nanomateriali, Nanotehnologii 2019 , т. 17 , № 4 , сс. $717-727$ (c) 2019 ІМФ (Інститут металофізики ім. Г. В. Курдюмова НАН України) Надруковано в Україні. Фотокопіювання дозволено тільки відповідно до ліцензі

PACS numbers: 78.55.Et, 78.66.Hf, 78.66.Jg, 78.67.Bf, 81.05.Dz

\title{
The Effect of the Doping Levels on Urbach Energy of the Zinc Oxide Thin Films
}

\author{
Yacine Aoun and Said Benramache
}

\author{
Material Sciences Department, \\ Faculty of Sciences, \\ University of Biskra, \\ 07000 Biskra, Algeria
}

Within the proposed model, the calculated Urbach energy of the undoped and $\mathrm{Bi}-, \mathrm{Sn}-$ and Fe-doped $\mathrm{ZnO}$ thin films is studied as a function of doping levels. The Bi-, Sn- and Fe-doped $\mathrm{ZnO}$ films were deposited by spray depositions at various conditions such as $\mathrm{ZnO}$-based solution molarity and doping levels. The measurements by means of this proposed model are found to be in a qualitative agreement with the experimental data with high correlation coefficients of 0.92-0.98. The Urbach-energy calculations for doped films are improved to maximum enhancement corresponding to minimum error, which is found for the $\mathrm{Sn}$ - and $\mathrm{Fe}$-doped $\mathrm{ZnO}$ films to be 5.5 and $5.1 \%$, respectively.

У рамках запропонованого моделю, розраховану енергію Урбаха нелегованих і легованих Бісмутом, Станумом і Ферумом тонких плівок ZnO вивчено як функцію рівнів легування. Леговані Бісмутом, Станумом і Ферумом плівки ZnO були нанесені осадженнями матеріялу, що розпорошується, за різних умов типу молярности розчину на основі $\mathrm{ZnO}$ та рівнів легування. Міряння за допомогою цього запропонованого моделю, як виявляється, перебувають у якісній згоді з експериментальними даними з високими коефіцієнтами кореляції у 0,92-0,98. Обчислення енергії Урбаха для легованих плівок поліпшено аж до максимального підвищення, що відповідає мінімальній помилці, яку знайдено для плівок $\mathrm{ZnO}$, легованих Станумом і Ферумом, рівною 5,5 і 5,1\% відповідно.

В этой работе, в рамках предложенной модели, рассчитанная энергия Урбаха нелегированных и легированных висмутом, оловом и железом тонких плёнок $\mathrm{ZnO}$ изучена как функция уровней легирования. Легированные висмутом, оловом и железом плёнки ZnO были нанесены осаждениями распыляемого материала в различных условиях типа молярности раствора на основе $\mathrm{ZnO}$ и уровней легирования. Измерения посредством этой предложенной модели, как обнаруживается, находятся в качественном согласии с экспериментальными данными с высокими коэффициентами 
корреляции 0,92-0,98. Вычисления энергий Урбаха для легированных плёнок улучшены вплоть до максимального повышения, соответствующего минимальной ошибке, которая найдена для плёнок $\mathrm{ZnO}$, легированных оловом и железом, равной 5,5 и 5,1\% соответственно.

Key words: $\mathrm{ZnO}$, thin film, semiconductor doping, correlation.

Ключові слова: $\mathrm{ZnO}$, тонка плівка, легування напівпровідника, кореляція.

Ключевые слова: $\mathrm{ZnO}$, тонкая плёнка, легирование полупроводника, корреляция.

(Received 14 August, 2019)

\section{INTRODUCTION}

In past years, the investigation of new materials for photovoltaic applications was depended and related to the experimental and modelling parameters of any properties. However, zinc oxide is one of the most important semiconductor materials for its semiconducting characteristics. It is an inorganic compound with the formula $\mathrm{ZnO}$, which has a wurtzite structure. This is a hexagonal crystal structure; $\mathrm{ZnO}$ is available as large bulk single crystals [1-4]. Transparent conducting oxides (TCO) (such as $\mathrm{ZnO}$ ) based glasses have gained much interest in science and technology; they are a unique class of materials based on metal oxides that exhibits both optical transparency, low resistivity, and good optical-gap energy due to their interesting applications such as transparent conductive, ferromagnetism, semiconductors, piezoelectric and solar cells [1-3]. However, in the past years, $\mathrm{ZnO}$ was used as primary films for a gas sensing due to their high optical transmission and high electrical conductivity. So far, $\mathrm{ZnO}$ as a thin film can be used with verity of investigated application for optoelectronic, piezoelectric, and photovoltaic applications such as sensors [4], thermoelectric devices [5], catalysis [6], fuel-cell electrodes [7], dye-sensitized solar cells (DSSCs) [8], and electrochromic material for displays [9].

$\mathrm{ZnO}$ is one of the most important binary II-VI semiconductor groups. The native doping of the semiconductor due to $\mathrm{O}$ vacancies or $\mathrm{Zn}$ interstitials is of $n$-type. $\mathrm{ZnO}$ has a wide-band gap of $3.37 \mathrm{eV}$ at room temperature and a large exciton binding energy $(60 \mathrm{meV})[9,10]$.

$\mathrm{ZnO}$ thin films can be produced by some techniques such as reactive evaporation, thermal annealing, molecular beam epitaxy, magnetron sputtered technique, low-temperature solution method, potentiostatic electrodeposition, sol-gel technique, pulsed laser deposition, chemical vapour deposition, electrochemical deposition, and spray pyrolysis 
[11-18], which have been reported to prepare thin films of $\mathrm{ZnO}$.

The main object of this work is to present a new-proposal model to calculate the Urbach energy of Bi-, Sn- and Fe-doped $\mathrm{ZnO}$ thin films; these estimations were studied by varying the precursor molarities and doping level of doped films.

\section{MATERIALS AND METHODS}

In this work, we have investigated a correlation to be used for study the relation between the Urbach energy and the preparing conditions of $\mathrm{ZnO}$ thin films, which were studied, the influence of evolution of the precursor molarity, doping level and the band-gap energy on Urbach energy. The optical properties of $\mathrm{ZnO}$ such as band-gap energy and the Urbach energy of undoped and doped films were taken from the literature [19-34] (Tables 1 to 4 ) to study the

TABLE 1. Experimental data [29]. Undoped $\mathrm{ZnO}$ thin films with $a \approx 3.28711$ and $b \approx 0.0184683$.

\begin{tabular}{|c|c|c|c|c|c|c|}
\hline 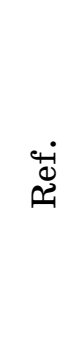 & 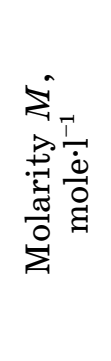 & 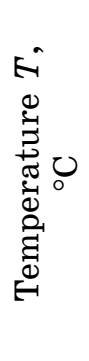 & 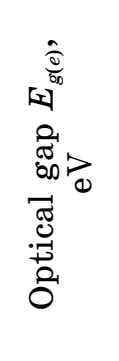 & 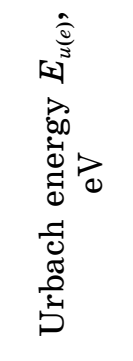 & 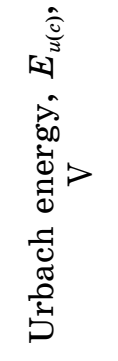 & 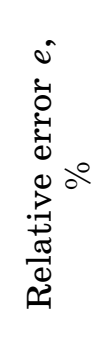 \\
\hline [19] & 0.05 & 350 & 3.08 & 0.9221 & 0.938 & 1.72 \\
\hline [19] & 0.075 & 350 & 3.22 & 0.3186 & 0.281 & 11.80 \\
\hline [19] & 0.1 & 350 & 3.37 & 0.085 & 0.069 & 18.82 \\
\hline [19] & 0.125 & 350 & 3.15 & 0.1757 & 0.201 & 14.39 \\
\hline [20] & 0.1 & 350 & 3.10 & 0.2734 & 0.279 & 2.05 \\
\hline [21] & 0.1 & 350 & 3.267 & 0.108 & 0.108 & 0 \\
\hline [22] & 0.02 & 350 & 3.19 & 0.08 & 0.071 & 11.25 \\
\hline [23] & 0.1 & 350 & 3.25 & 0.064 & 0.074 & 15.62 \\
\hline [24] & 0.1 & 350 & 3.304 & 0.1139 & 0.101 & 11.32 \\
\hline [25] & 0.1 & 350 & 3.317 & 0.0983 & 0.097 & 1.32 \\
\hline [26] & 0.1 & 350 & 3.27 & 0.17 & 0.165 & 2.94 \\
\hline [27] & 0.1 & 350 & 3.25 & 0.209 & 0.203 & 2.87 \\
\hline [28] & 0.1 & 350 & 3.23 & 0.490 & 0.444 & 9.39 \\
\hline
\end{tabular}

Note: $E_{g(e)}$-experimental optical-gap energy; $E_{u(e)}$-experimental Urbach energy; $E_{u(c)}$-correlate Urbach energy. 
TABLE 2. Experimental data and the Urbach energy correlate for Bi-doped $\mathrm{ZnO}$ thin films with 0.02 mole $\cdot 1^{-1}, A \approx-1.37139$ and $B \approx-39.00365$.

\begin{tabular}{|c|c|c|c|c|c|c|}
\hline 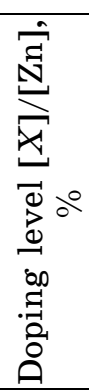 & 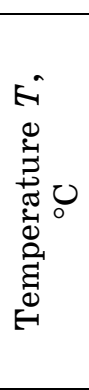 & 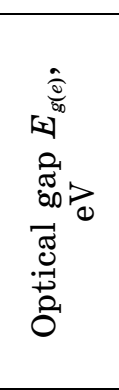 & 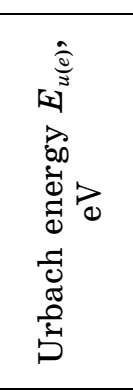 & 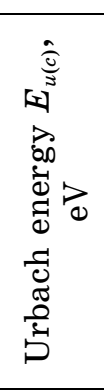 & 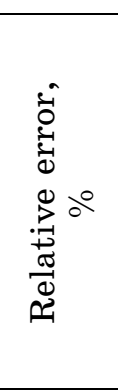 & 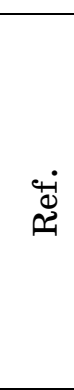 \\
\hline 0 & 350 & 3.19 & 0.08 & 0.071 & 11.25 & \multirow{6}{*}{ [22] } \\
\hline 1 & 350 & 3.195 & 0.011 & 0.035 & - & \\
\hline 2 & 350 & 3.21 & 0.08 & 0.081 & 1.25 & \\
\hline 3 & 350 & 3.21 & 0.095 & 0.102 & 7.37 & \\
\hline 4 & 350 & 3.225 & 0.52 & 0.487 & 6.34 & \\
\hline 5 & 350 & 3.239 & 0.53 & 0.498 & 6.04 & \\
\hline 0 & 450 & 3.250 & 0.2527 & 0.281 & 11.19 & \multirow{4}{*}[30]{} \\
\hline 1 & 450 & 3.240 & 0.4159 & 0.454 & 9.16 & \\
\hline 3 & 450 & 3.200 & 0.4573 & 0.465 & 1.68 & \\
\hline 5 & 450 & 3.120 & 0.4954 & 0.462 & 6.74 & \\
\hline
\end{tabular}

effect of precursor molarity, doping level and substrate temperature on physical properties of undoped and doped $\mathrm{ZnO}$ thin films with $\mathrm{Bi}$, Sn and Fe. The thin films were deposited on glass substrates by chemical spray ultrasonic and pyrolysis techniques. The proposal model to calculate the Urbach energy of $\mathrm{Bi}$-, Sn-, and Fe-doped $\mathrm{ZnO}$ thin films was based on estimation for the undoped films that is found in nonlinear format as expressed in Ref. [29].

\subsection{The Urbach Energy Evaluated}

The Urbach energy for $\mathrm{ZnO}$ thin films was calculated by Eq. (1) [29]:

$$
E_{u}=\exp \left(\ln M+\frac{1}{b} \ln \frac{a}{E_{g}}\right) \pm \Delta E_{u}, \text { if } X_{0}=0,
$$

where $E_{u}$-Urbach energy [meV]; $a, b$-empirical constants for undoped film; $M$-concentration molarity (mole/l); $\Delta E_{u}$ is the resulting error for Urbach energy; $E_{g}$ is the optical-band gap, and $X_{0}$ is the doping concentration. 
In this work, the estimate of the Urbach energy for doped $\mathrm{ZnO}$ thin films was investigated by the following Eq. (2):

$$
E_{u}=\exp \left(\ln M+\frac{1}{b\left(1+B X_{0}\right)} \ln \frac{a\left(1+A X_{0}\right)}{E_{g}}\right) \pm \Delta E_{u}, \text { if } X_{0}>0
$$

where $A, B$-empirical constants for doped film; $E_{g}$-optical-gap energy [eV]; $X_{0}$-concentration of doping [\%].

The resulting errors for Urbach energy $\left(\Delta E_{u}\right)$ can be measured from Eqs. (1), (2) by the following relationships as expressed in Eqs. (3), (4) [35]:

$$
\begin{gathered}
\ln E_{g}-\ln \left(a\left(1+A X_{0}\right)\right)=\left(b\left(1+B X_{0}\right)\right)\left[\ln M-\ln E_{g}\right] \\
\left(b\left(1+B X_{0}\right)\right)\left(\frac{d E_{u}}{E_{u}}-\frac{d M}{M}\right)+d\left(b\left(1+B X_{0}\right)\right)\left(\ln E_{u}-\ln M\right)= \\
=\frac{d\left(a\left(1+A X_{0}\right)\right)}{\left(a\left(1+A X_{0}\right)\right)}-\frac{d E_{g}}{E_{g}} .
\end{gathered}
$$

The difference found about the doping concentration of doped thin films was limited, so we have $d\left(a\left(1+A X_{0}\right)\right)=0$ and $d\left(b\left(1+B X_{0}\right)\right)=0$.

Equation (4) can be written in the following form of Eqs. (5), (6):

$$
\begin{gathered}
\left(b\left(1+B X_{0}\right)\right) \frac{\Delta E_{u}}{E_{u}}=\frac{\Delta E_{g}}{E_{g}}, \\
\Delta E_{u}=\frac{1}{\left(b\left(1+B X_{0}\right)\right)} \frac{\Delta E_{g}}{E_{g}} E_{u} .
\end{gathered}
$$

\subsection{The Relative Error Measurement}

The relative error value was measured between the experimental data and correlate values by the following Eq. (7):

$$
\varepsilon=\left|\left(E_{\text {u exp }}-E_{\text {u corr }}\right) / E_{g \text { exp }}\right| \cdot 100 \text {. }
$$

The correlation coefficient $R$ depends on both relative errors and doping via Eq. (8):

$$
R=1-\frac{\sum_{i=1}^{N} \varepsilon_{i}}{N}
$$


TABLE 3. Experimental data and the Urbach energy correlate for Sn-doped $\mathrm{ZnO}$ thin films with 0.2 mole $\cdot \mathrm{l}^{-1}, A \approx-1.91294$ and $B \approx 33.62015$.

\begin{tabular}{|c|c|c|c|c|c|c|}
\hline 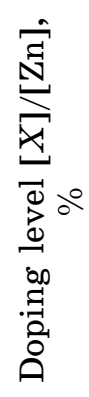 & 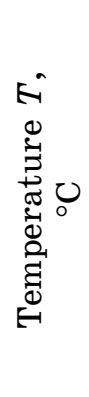 & 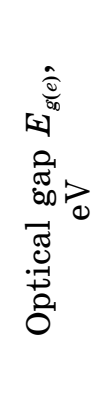 & 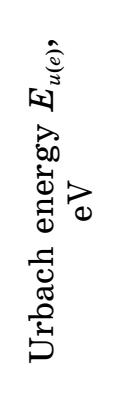 & 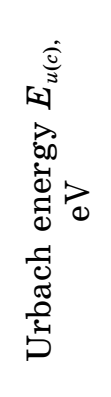 & 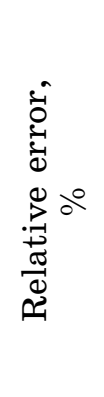 & $\begin{array}{l}\text { ये } \\
\text { स्य }\end{array}$ \\
\hline 0 & 450 & 3.37 & 0.055 & 0.052 & 5.00 & \multirow{4}{*}{ [31] } \\
\hline 1 & 450 & 3.26 & 0.054 & 0.053 & 1.85 & \\
\hline 3 & 450 & 3.25 & 0.058 & 0.058 & 0.83 & \\
\hline 5 & 450 & 3.18 & 0.058 & 0.089 & 1.02 & \\
\hline 0 & 400 & 3.125 & 0.301 & 0.411 & - & \multirow{4}{*}{ [32] } \\
\hline \multirow[t]{2}{*}{1} & 400 & 3.03 & 0.675 & 0.655 & 2.90 & \\
\hline & 400 & 2.985 & 1.143 & 1.161 & 1.56 & \\
\hline 2 & 400 & 2.88 & 1.352 & 1.427 & 5.53 & \\
\hline
\end{tabular}

TABLE 4. Experimental data and the Urbach energy correlate for Fe-doped ZnO thin films with $A \approx-13.92950$ and $B \approx-941.53779$.

\begin{tabular}{|c|c|c|c|c|c|c|c|}
\hline 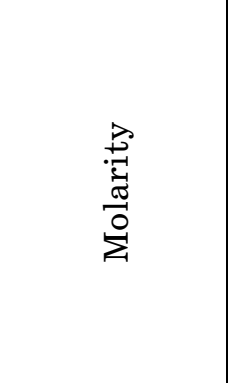 & 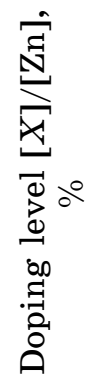 & 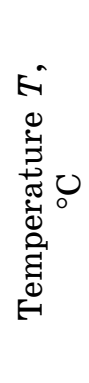 & 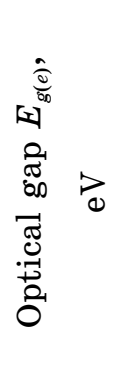 & 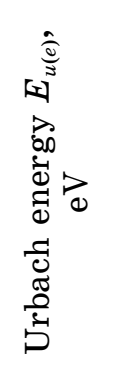 & 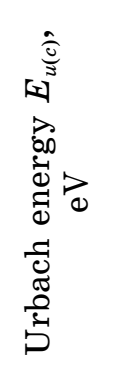 & 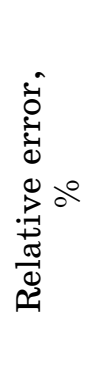 & 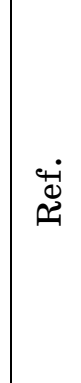 \\
\hline \multirow{3}{*}{0.2 mole $\cdot \mathrm{l}^{-1}$} & 0 & 300 & 3.29 & 0.073 & 0.074 & 1.37 & \multirow{3}{*}{ [33] } \\
\hline & 1 & 300 & 2.67 & 0.136 & 0.131 & 3.67 & \\
\hline & 2 & 300 & 2.75 & 0.136 & 0.129 & 5.14 & \\
\hline \multirow{4}{*}{0.01 mole $\cdot 1^{-1}$} & 0 & 410 & 3.255 & 0.081 & 0.085 & 4.93 & \multirow{4}{*}{ [34] } \\
\hline & & 410 & 3.115 & 0.164 & 0.165 & 0.61 & \\
\hline & 1.5 & 410 & 3.135 & 0.197 & 0.196 & 0.51 & \\
\hline & 2 & 410 & 3.105 & 0.219 & 0.215 & 1.82 & \\
\hline
\end{tabular}


Table 1 presents the summary results of experimental data, which were obtained from published papers and the correlated Urbach energy and relative error for undoped $\mathrm{ZnO}$ thin films [19].

\section{RESULTS AND DISCUSSION}

Figure 1 shows the variation of experimental and correlate Urbach energy for undoped $\mathrm{ZnO}$ thin films.

The correlate values were scaled parameter values according to Eq. (1), as represented in Table 1, which were estimated as a function of solution molarity and optical energy. As can be seen, all estimated values are proportional to the experimental data. Thus, the calculations by the proposed equations are in qualitative agreement with the experimental data, so it is found that the correlation coefficient is of about 0.92 , i.e. the maximum agreement of the estimation was found to be minimum error.

Table 2 presents the summary results of experimental data and the Urbach energy correlate for Bi-doped $\mathrm{ZnO}$ thin films, which are calculated from Eq. (2).

Table 3 presents the summary results of experimental data and the Urbach energy correlate for Sn-doped $\mathrm{ZnO}$ thin films, which are calculated from Eq. (2).

Table 4 presents the summary results of experimental data and the Urbach energy correlate for Fe-doped $\mathrm{ZnO}$ thin films, which are calculated from Eq. (2).

As shown in Fig. 2, the doping evolution of $\mathrm{Bi}-$, $\mathrm{Sn}-$, and $\mathrm{Fe}-$ doped $\mathrm{ZnO}$ thin films influence on the estimation of Urbach energy with doping levels and their optical-gap energy; here, the investiga-

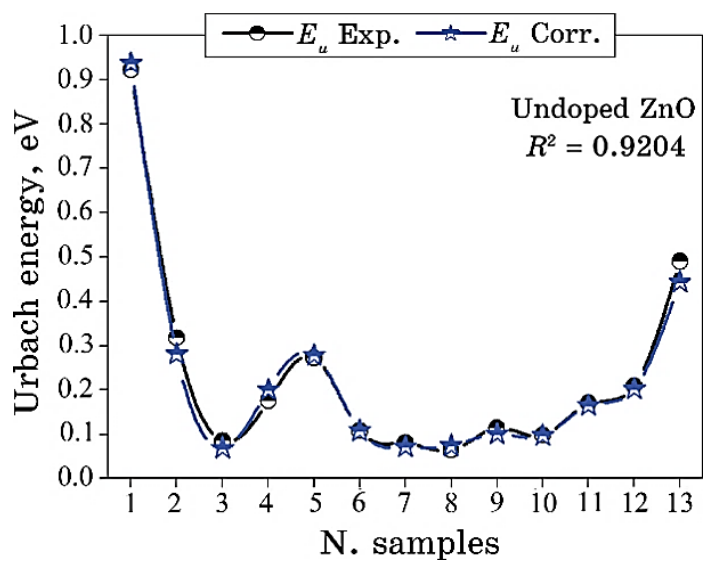

Fig. 1. The variation of Urbach energy experimental. 

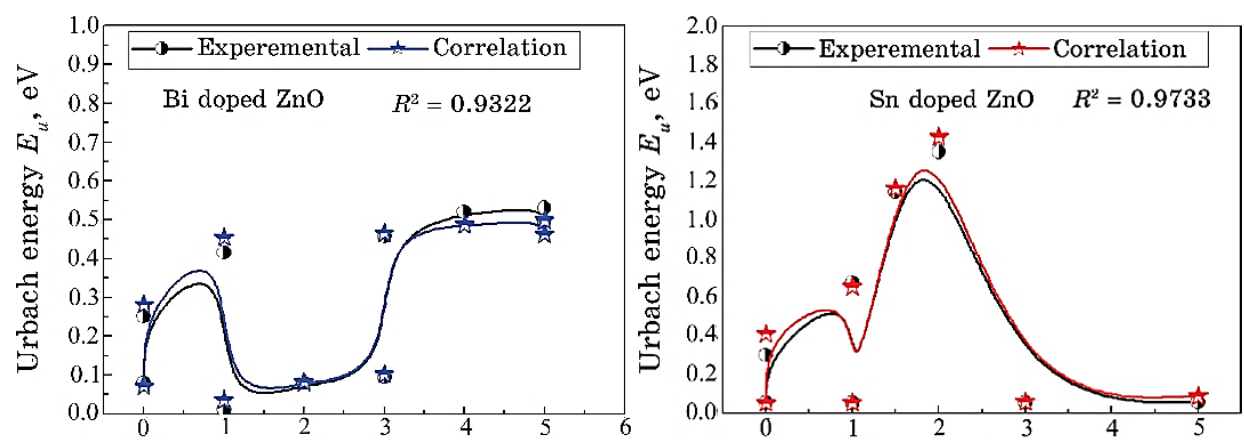

Bi concentration $X_{\mathrm{Bi}}$, wt. $\%$

Sn concentration $X_{\mathrm{Sn}}$, wt.\%

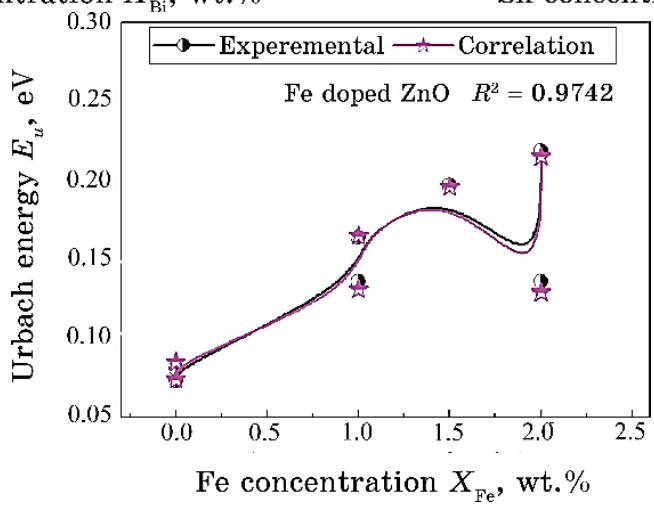

Fig. 2. The variation of Urbach energy experimental and correlate of $\mathrm{Bi}$-, Sn-, and Fe-doped $\mathrm{ZnO}$ thin films.

tions were carried out on the basis of Eq. (2).

As can be seen in Fig. 2 with comparing with undoped films, the estimation of Urbach energy in the Bi-, Sn-, and Fe-doped films have a high correlation coefficient of $0.9322,0.9733$ and 0.9742 , respectively. Besides, the calculation values are in qualitative agreement with the experimental data, i.e. the maximum agreement of the estimations was found to be with minimum relative error.

In Figures 3 and 4, we obtained that the relative errors of Urbach energy of undoped and doped thin films, respectively.

For undoped films, all calculations have errors smaller than $18 \%$, however, we found after calculate that the relative error of the Urbach energy for doped films are improved, and the maximum enhancement of minimum errors was found for $\mathrm{Sn}$ - and $\mathrm{Fe}$-doped $\mathrm{ZnO}$ thin films with 5.53 and $5.14 \%$, respectively. It was confirmed that these models are suitable for calculation of optical properties with varying of some parameters. The decreases in the relative errors for undoped films to doped ones can be explained by the good optical properties, which can be observed with the fewer defects and less 


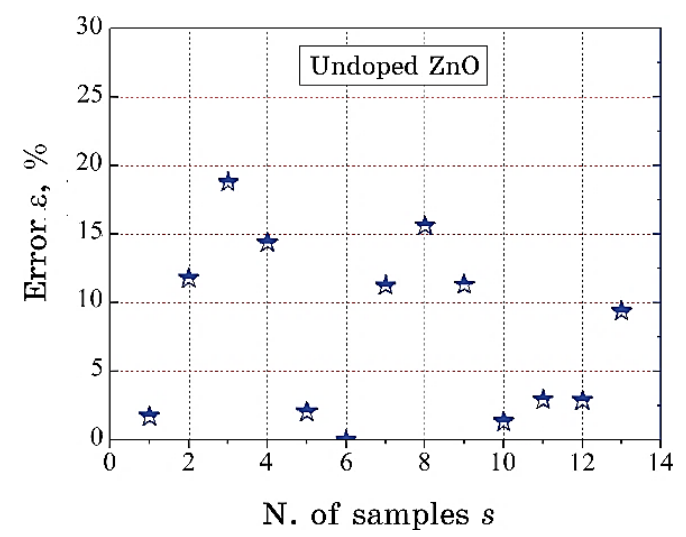

Fig. 3. The variation of error value of calculated Urbach energy for undoped $\mathrm{ZnO}$ thin films.

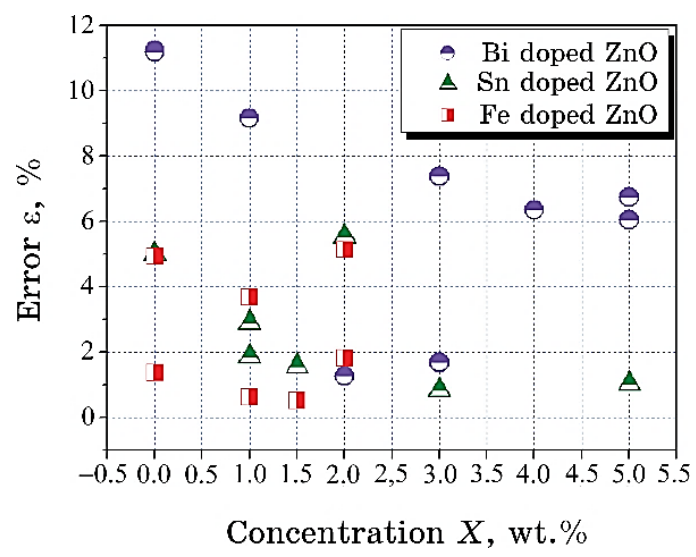

Fig. 4. The variation of error value of calculated Urbach energy for Bi-, Sn-, and Fe-doped $\mathrm{ZnO}$ thin films.

disorder.

\section{CONCLUSIONS}

In summary, the undoped $\mathrm{ZnO}$ and $\mathrm{Bi}-$, Sn-, and Fe-doped $\mathrm{ZnO}$ films were chosen for studying the calculation of Urbach energy with same variations. Thin films were investigated by spray techniques such as ultrasonic and pyrolysis. The model proposed to calculate the Urbach energy of undoped and doped $\mathrm{ZnO}$ thin films were investigated. These relations suggest that the Urbach energy can be estimated by variations of optical-gap energy, concentration of $\mathrm{ZnO}$ 
solution and doping level. The measurements by means of these proposed models are in qualitative agreement with the experimental data that has been reliable in this work, because of the high correlation coefficients, which were found to be in the range $0.92-0.98$.

Thus, it is found that the relative errors for undoped $\mathrm{ZnO}$ films in all calculation are smaller than $18 \%$. However, we found after calculate that the relative errors of the Urbach energy for doped films are improved with the maximum enhancement corresponding to minimum errors for Sn- and Fe-doped $\mathrm{ZnO}$ thin films, which are equal to 5.53 and $5.14 \%$, respectively. As confirmed, these models are suitable for calculation of Urbach energy with variation of some parameters. The decreases in the relative errors of undoped $\mathrm{ZnO}$ to doped $\mathrm{ZnO}$ films can be explained by the good optical properties, which can be observed with the fewer defects and less disorder.

\section{REFERENCES}

1. Y. Aoun, B. Benhaoua, B. Gasmi, and S. Benramache, Main Group Chemistry, 14: 27 (2015).

2. O. Belahssen, S. Benramache, and B. Benhaoua, Main Group Chemistry, 13: 343 (2014).

3. M. Yilmaz, Materials Science in Semiconductor Processing, 40: 99 (2015).

4. S. Kushwaha and L. Bahadur, Optik, 124: 5696 (2013).

5. J. Lee and Y. S. Park, Thin Solid Films, 587: 94 (2015).

6. P. Lv, L. Lin, W. Zheng, M. Zheng, and F. Lai, Optik, 124: 2654 (2013).

7. F. Xian, K. Miao, X. Bai, Y. Ji, F. Chen, and X. Li, Optik, 124: 4876 (2013).

8. S. Benramache, S. Gaerh, B. Benhaoua, A. Darsouni, O. Belahssen, and H. Ben Temam, Journal of Chemistry and Materials Research, 2: 59 (2015).

9. S. Benramache, A. Arif, O. Belahssen, and A. Guettaf, Journal of Nanostructure in Chemistry, 3, No. 80: 1 (2013).

10. F. Benharrats, K. Zitounia, A. Kadria, and B. Gilb, Superlattices and Microstructures, 47: 592 (2010).

11. S. Rahmane, M. A. Djouadi, M. S. Aida, N. Barreau, B. Abdallah, and N. Hadj Zoubir, Thin Solid Films, 519: 5 (2010).

12. Y. D. Ko, K. C. Kim, and Y. S. Kim, Superlattices and Microstructures, 51: 933 (2012).

13. E. F. Keskenler, G. Turgut, and S. Dogăn, Superlattices and Microstructures, 52: 107 (2012).

14. C. C. Ting, C. H. Li, C. Y. Kuo, C. C. Hsu, H. C. Wang, and M. H. Yang, Thin Solid Films, 518: 4156 (2010).

15. R. E. Marotti, P. Giorgi, G. Machado, and E. A. Dalchiele, Solar Energy Materials \& Solar Cells, 90: 2356 (2006).

16. J. Ramesh, G. Pasupathi, R. Mariappan, V. Senthil Kumar, and V. Ponnuswamy, Optik, 124: 2023 (2013).

17. S. Benramache, B. Benhaoua, N. Khechai, and F. Chabane, Matériaux \& Techniques, 100: 573 (2012). 
18. S. Benramache and B. Benhaoua, Superlattices and Microstructures, 52: 1062 (2012).

19. S. Benramache, O. Belahssen, A. Guettaf, and A. Arif, Journal of Semiconductors, 34: 113001 (2013).

20. A. Gahtar, S. Benramache, B. Benhaoua, and F. Chabane, Journal of Semiconductors, 34: 073001 (2013).

21. B. Benhaoua, A. Rahala, and S. Benramache, Superlattices and Microstruc tures, 68: 38 (2014).

22. F. Chouikh, Y. Beggah, and M. S. Aida, Journal of Materials Science: Mate rials Electronic, 22: 499 (2011).

23. N. Zebbar, Y. Kheireddinea, K. Mokeddema, A. Hafdallahb, M. Kechouanea, and M. S. Aida, Science in Semiconductor Processing, 14: 229 (2011).

24. S. Ilican, Y. Caglar, M. Caglar, and F. Yakuphanoglu, Physica E, 35: 131 (2006).

25. A. Rahal, S. Benramache, and B. Benhaoua, Engineering Journal, 18: 81 (2014).

26. B. L. Zhu, X. H. Sun, X. Z. Zhao, F. H. Su, G. H. Li, X. G. Wu, J. Wu, R. Wu, and J. Liu, Vacuum, 82: 495 (2008).

27. S. Benramache and B. Benhaoua, Superlattices and Microstructures, 52: 807 (2012).

28. A. Hafdallah, F. Yanineb, M. S. Aida, and N. Attaf, Journal of Alloys and Compounds, 509: 7267 (2011).

29. O. Belahssen, H. Ben Temam, and S. Benramache, International Journal of Renewable Energy Research, 5: 177 (2015).

30. N. S. Kumar, C. Anandan, and G. K. Shivakumar, Journal of Alloys Com pounds, 578: 613 (2013).

31. S. Aksoy, Y. Caglar, S. Ilican, and M. Caglar, Optica Applicata, 1: 7 (2010).

32. C. S. Prajapati, A. Kushwaha, and P. P. Sahay, Applied Physics, 113: 651 (2013).

33. C. S. Prajapati, A. Kushwaha, and P. P. Sahay, Materials Research Bulletin, 48: 2687 (2013).

34. C. S. Prajapati, A. Kushwaha, and P. P. Sahay, Journal of Thermal Spray Technology, 22: 1230 (2013).

35. S. Benramache, B. A. Benhaoua, and O. Belahssen, Journal of Chemistry and Materials Research, 4: 19 (2015). 